\title{
When Stakeholder Representation Leads to Faultlines. A Study of Board Service Performance in Social Enterprises
}

\section{ABSTRACT}

Following the growing interest in sustainability and ethics, organizations are increasingly attentive to accountability toward stakeholders. Stakeholder representation, obtained by appointing board members representing different stakeholder groups, is suggested to be a good ethical practice. However, such representation may also have nefarious implications for board functioning. Particularly, it may result in strong faultline emergence, subsequently mitigating board performance. Our study aims at understanding the process through which faultlines affect board performance, and particularly the board service role through which the board is involved in providing counsel and strategic decision-making. We study the relationship between faultlines and board service performance in the particularly relevant context of social enterprises. We find that faultline strength is negatively related to board service performance and that this relationship is mediated by board task conflict. Furthermore, our study reveals the importance of clear and shared organizational goals in attenuating the negative effects of faultlines.

\section{Keywords:}

Board service performance, faultlines, governance, stakeholder representation, social enterprises 


\section{INTRODUCTION}

Corporate citizenship, sustainability and ethics in organizational contexts are increasingly receiving notice (Aguinis and Glavas, 2012), thus bringing increased attention to accountability toward different stakeholders and the social responsibility of organizations (Carroll, 2015), as well as giving rise to an active discussion about stakeholder democracy (Matten and Crane, 2005; Van Buren III, 2010). Stakeholder democracy refers to "stakeholder participation in processes of organizing, decision-making, and governance in corporations" (Matten and Crane, 2005, p. 6). It is considered a best ethical practice or even an ethical obligation (Hendry, 2001; Moriarty, 2014; O'Dwyer, 2005): Van Buren III (2010) argues that, as stakeholders contribute to the value creation of organizations, they should also have the right to participate in the decision-making and corporate governance processes. Through stakeholder participation, stakeholders are not just considered as a means, but are also an end, in and of themselves (Evan and Freeman, 1993; Hielscher et al., 2014). As taking into consideration stakeholder demands is considered crucial for organizational health (Moriarty, 2014), stakeholder participation is expected to ultimately benefit both society and organizations (Harrison and Freeman, 2004).

However, despite the centrality of stakeholder democracy in ethical discussions, the literature devotes considerable attention to the participation of only one particular stakeholder group, namely employees (Harrison and Freeman, 2004; Matten and Crane, 2005; Moriarty, 2010), referred to as workplace democracy (Matten and Crane, 2005; Timming, 2015). Notwithstanding this empirical emphasis on the employees as stakeholders, the board of directors, as the ultimate decision-making body in organizations, is considered to play a crucial role in effectuating stakeholder participation (Moriarty, 2010; Van Buren III, 2010). Indeed, it is commonly accepted that one of the best ways to provide a diverse range of stakeholders with greater voice is through appointments to the board of directors (Harrison and Freeman, 2004; Moriarty, 2014). Researchers allude to the potentially positive aspects of stakeholder 
democracy through board appointments (hereafter: stakeholder representation). Specifically, it is considered a best practice from an ethical perspective as it enables the organization to share power with all stakeholders (Moriarty, 2014; Van Buren III, 2010). Furthermore, stakeholder representation may often help in gaining legitimacy from different stakeholder groups, which is crucial for the acquisition of resources, including financial and human resources (Doherty et al., 2014; Miller et al., 2012). By contrast, other researchers allude to the potentially nefarious effects of stakeholder representation on the board, which is related to slower decision-making and the lack of knowledge of stakeholder representatives (Harrison and Freeman, 2004; Hielscher et al., 2014; Matten and Crane, 2005). Consequently, it is likely for stakeholder representation to affect board functioning. Boards typically engage in two different roles, referred to as the control role (Okhmatovskiy and David, 2012) and the service role (Fiegener, 2005; Forbes and Milliken, 1999; Zahra and Pearce, 1989). It is through the service role that the board is involved in enhancing the firm's reputation, establishing contacts with the external environment, as well as giving counsel and advice to executives (Minichilli et al., 2009; Zahra and Pearce, 1989). As such, it is likely for stakeholder representation to particularly affect the engagement of the board in its service role. Surprisingly, however, there is a dearth of research into the implications of stakeholder representation on boards of directors in general and, specifically, the board's service role.

Our study focuses on understanding the link between stakeholder representation and the engagement of the board in its service role (hereafter referred to as "board service performance;" similar terms used in the literature include "board service task performance" (Minichilli et al., 2009), "board engagement in the service role" (Knockaert and Ucbasaran, 2013), and "board service involvement" (Knockaert et al., 2015). In doing so, we focus on a relevant organizational behavior concept and related theories, namely faultlines. A faultline perspective is particularly relevant as stakeholder representation is suggested to lead to the 
formation of subgroups (Pache and Santos, 2010; Smith et al., 2013). Organizational behavior scholars point to the importance of studying the behavior of subgroups and suggest focusing on faultline emergence as an important mechanism (Bezrukova et al., 2012; Thatcher and Patel, 2012). Faultlines are hypothetical dividing lines splitting a group into relatively homogeneous subgroups, based on the alignment of individuals along multiple characteristics, possibly leading to conflicts (Lau and Murnighan, 1998). However, our knowledge on either the relationship between stakeholder representation and faultlines, or the relationship between board faultlines and the subsequent board and organizational performance (Almandoz, 2012) is still limited. Our study aims at investigating the practice of stakeholder representation on the board, thereby focusing on board service performance and the extent to which stakeholder representation may affect such performance through the emergence of faultlines.

In aiming for its research objectives, our study considers a particularly relevant context, namely that of social enterprises, which engage in commercial activities to solve social problems and, as such, have a dual mission of financial sustainability and social goal achievement (Battilana et al., 2015; Doherty et al., 2014). First, from a stakeholder perspective, social enterprises are particularly relevant as they lack a dominant external stakeholder and are exposed to the conflicting expectations and demands of different principal stakeholder groups (Ebrahim and Rangan, 2014; Mair et al., 2015; Ramus and Vaccaro, 2014). To address such conflicting demands, social enterprises often have multi-stakeholder boards (Kerlin, 2006; Spear et al., 2009).

Second, any entrepreneurial firm faces challenges that make a board service role perspective particularly relevant (Hillman and Dalziel, 2003; Knockaert and Ucbasaran, 2013; Minichilli et al., 2009). However, in addition to general entrepreneurial challenges, social enterprises face specific external and internal tensions (Battilana and Lee, 2014). External tensions are related to the need to establish legitimacy and obtain support from different stakeholder groups. 
Internal tensions are related to balancing the social and economic goals while avoiding mission drift; for instance when making decisions on resource allocation (Ashforth and Reingen, 2014). As such, through engaging in the service role, boards may be particularly important in helping social enterprises deal with these external and internal tensions (Battilana and Lee, 2014; Ebrahim et al., 2014; Mair et al., 2015; Pache and Santos, 2013; Spear et al., 2009). Consequently, while boards of directors in social enterprises are largely neglected in academic research (Spear et al., 2009), they are of utmost importance as they set the overall framework within which these organizations operate and make critical decisions (Battilana and Lee, 2014; Mair et al., 2015), thus affecting organizational effectiveness (Ostrower and Stone, 2006).

Accordingly, this paper aims at unraveling the implications of stakeholder representation on boards of organizations. We specifically study the relationship between faultlines originating from stakeholder representation and the engagement of the board in its service role. By subsequently unraveling the mechanisms and contingencies through which faultlines are related to such performance, we aim at contributing to the business ethics, (social) entrepreneurship, corporate governance, and organizational behavior literatures in a number of ways.

First, we add to the literature on stakeholder democracy and stakeholder participation by leaving the beaten paths of workplace democracy to focus on stakeholder representation as a largely neglected aspect source of stakeholder democracy. Specifically, we introduce faultline emergence as a potentially nefarious consequence of stakeholder representation in corporate governance mechanisms in organizations in general. This paper also explicitly responds to calls to focus on the governance function in social enterprises (Battilana and Lee, 2014; Mair et al., 2015) and to specifically study stakeholder representation and subgroup formation in order to better understand the relationship between corporate governance practices and board performance in social enterprises (Almandoz, 2014; Doherty et al., 2014; Pache and Santos, 
2010). This research further contributes to the extensive body of entrepreneurship literature that considers top management and boards as groups of individuals, or teams, and that is pointing to faultlines as a promising theoretical avenue (Lim et al., 2013), but is yet to incorporate the concept either theoretically or empirically.

Second, we respond to calls in the corporate governance literature to open up the black box of board dynamics (Hambrick et al., 2008; Huse et al., 2011; Van Ees et al., 2009). Specifically, Ostrower and Stone (2010) call for studies into a wider range of board member characteristics than just demographics such as race and gender. Further, as Westphal and Zajac (2013) and Knockaert and Ucbasaran (2013) highlight, while much of the corporate governance literature takes an agency theoretical perspective in studying the (control) role of the board, other (behavioral) theoretical perspectives may be more relevant when studying the service role of the board. Importantly, we respond to a call by Cornforth (2012), who argues that corporate governance research is often focused on boards in unitary organizations and calls for studies into the governance of organizations with more complex governance structures, such as social enterprises.

Finally, we add to the organizational behavior literature, which introduced and widely studies faultlines. So far, however, faultline research mainly focuses on age, gender and ethnicity as social category characteristics that may give rise to faultline emergence (Thatcher and Patel, 2012). We add to this literature by introducing stakeholder representation as a potentially important social category characteristic (Van der Brempt et al., 2015).

The paper unfolds along the following lines. First, we systematically develop a number of hypotheses on the relationship between faultlines and the board's service role. We integrate these hypotheses in a theoretical framework that is geared toward a better understanding of the relationship between stakeholder representation at board level and board service performance, just as the intermediate mechanisms in the relationship. In a following section, we describe the 
research method, including the research setting, the description of the sample, data collection and operationalization of the variables. After presenting our results, we discuss the main conclusions and contributions of our paper, as well as the limitations and directions for future research.

\section{A FAULTLINE THEORETICAL PERSPECTIVE}

As articulated above, the representation of different stakeholder groups is often considered to be a good practice in balancing the competing demands of stakeholders in the decision-making process (Moriarty, 2014; Pache and Santos, 2010). At the same time, several authors warn of the potentially negative effects of stakeholder representation (Pache and Santos, 2010). Specifically, stakeholder representation may contribute to subgroup emergence. Tensions between different subgroups on the board can make it difficult to achieve a clear purpose, as such slowing down the decision-making process (Huybrechts, 2010; Spear et al., 2009). Pache and Santos (2010, p. 468) even warn for 'dramatic outcomes'. Specifically, escalations of conflict may result in organizational paralysis or even permanent organizational breakups. However, the literature offers little explanation of the conditions under which the emergence of subgroups may negatively influence board performance (Almandoz, 2014). A possible explanation can be found in faultline theory, studying the emergence of subgroups and its effect on group dynamics and performance. While faultlines may originate from social category, informational and personality differences (Thatcher and Patel, 2012), we introduce the representation of different stakeholder groups in the board of directors as an additional social category characteristic triggering faultline emergence.

In what follows, we build upon faultline theory and literature, linking faultlines to board service performance. Then, we add a conflict theoretical perspective to explain the process through which faultline strength may affect board service performance. Finally, we explore which 
contingency factors could affect the earlier hypothesized relationships. The framework we present is summarized in Figure 1 and serves as a guide throughout the remainder of this section.

\section{INSERT FIGURE 1 ABOUT HERE}

\section{The origin and nature of faultlines}

The faultline concept has its origin in research on group diversity and heterogeneity. Although group members' traits are important for the way they address issues, it is the heterogeneity or homogeneity of these traits among group members that affects how they cooperate (Tuggle et al., 2010). Research on group diversity reveals that diversity may have positive as well as negative effects on group performance (van Knippenberg et al., 2011). Indeed, diversity in a group can be a source of knowledge, information and expertise, leading to improved performance. This argument is in line with the earlier mentioned positive effects of stakeholder representation in groups, or boards of directors specifically (Diochon, 2010; Smith, 2010). On the other hand, diversity is also a potential source of conflict, engendering subgroups that may disrupt group processes and, consequently, group performance. Similarly, stakeholder representation, or diversity in the stakeholder groups represented in the board, may lead to negative effects (Pache and Santos, 2010; Spear et al., 2009). Harrison and Klein (2007) refer to these effects of group diversity as 'diversity as variety' versus 'diversity as separation'. Whereas the first refers to group members bringing a multiplicity of perspectives and experiences, the latter points to these members holding different positions or opinions on taskor team-related issues. By consequence, whereas variety enhances creativity and decision quality, separation typically reduces cohesiveness and subsequent task performance (Harrison and Klein, 2007). 
Following the mixed findings on the effects of group heterogeneity, calls have been made to introduce more sophisticated models of diversity that are superior in predicting the negative or positive effects of diversity (Lau and Murnighan, 1998; Tuggle et al., 2010; van Knippenberg et al., 2011). The introduction of the faultline concept by Lau and Murnighan (1998) can be considered as a fruitful avenue to answer these calls. Group faultlines are defined as hypothetical dividing lines that may split a group into subgroups based on alignment along multiple attributes (Bezrukova et al., 2009; Lau and Murnighan, 1998). In the faultlines reasoning, different dimensions of diversity are studied in conjunction instead of looking at different traits separately (Rico et al., 2007). The theoretical mechanisms used to explain the emergence and the effects of faultlines are self-categorization, social identification, and similarity attraction (Thatcher and Patel, 2012). Self-categorization and social identity theories explain how individuals, in order to define their identities and to protect their self-esteem, classify themselves and others into social categories. As a result of such categorization, individuals favor and trust their group members more than individuals of other groups (Lau and Murnighan, 2005; Rico et al., 2007). The similarity-attraction paradigm refers to the tendency of people to like, trust and cooperate with similar others (Li and Hambrick, 2005; van Knippenberg et al., 2011).

Although it is generally accepted that faultlines can form around many characteristics (Lau and Murnighan, 2005; Thatcher and Patel, 2012), the majority of faultline research focuses on faultlines based on demographic social category characteristics, i.e. the characteristics of age, gender and ethnicity. In addition, informational or task-related characteristics are studied in faultline research (Rico et al., 2007; Thatcher and Patel, 2012). Informational characteristics are underlying attributes that are directly job-related, such as functional background, tenure, and education (Bezrukova et al., 2009; Rico et al., 2007). While less frequently studied (Thatcher and Patel, 2012), personality traits and values are also considered a potential source 
of faultline emergence. Conscientiousness and emotional stability are examples of personality traits that are examined in faultline research (Molleman, 2005; Rico et al., 2007). In the context of faultlines in boards, board tenure, education level, functional background, industry background and type of directorship (executive versus non-executive directors) (Kaczmarek et al., 2012; Tuggle et al., 2010), in addition to general demographic characteristics like age and gender (Veltrop et al., 2015), are studied. So far, research neglects faultlines originating from the representation of different stakeholder groups as one of the driving characteristics. In what follows, we elaborate on how strong faultlines in the board, to which stakeholder representation contributes, may affect board service performance, and then subsequently elaborate on potential mediator and moderator relationships.

\section{The relationship between faultline strength and board service performance}

It is generally accepted that faultlines are particularly detrimental to the organization if they are strong. Faultline strength increases when subgroups are homogeneous as subgroup members are then more similar, while more strongly differing from members of others subgroups with whom they do not share attributes (Lim et al., 2013). Indeed, following faultline theory, strong faultlines will result in reduced information exchange and increased problems in providing constructive advice, which in turn has a negative impact on joint decision-making and the ability to reach a strategic consensus (Li and Hambrick, 2005; Minichilli et al., 2009). Generally, strong competition between the subgroups results in less time and energy spent on essential tasks, thus distracting from the organizational goals (Thatcher and Patel, 2012).

Based on social identity theory and similarity attraction, we introduce stakeholder representation as an additional relevant social category characteristic in faultline research. Indeed, board members will quickly identify which stakeholder groups other board members represent. Based upon faultline theory, we argue that faultlines will emerge following the 
alignment of stakeholder representation with other important social category characteristics, such as age and gender. We argue that, if strong faultlines exist based on the alignment of these social category characteristics, board members form identity-based subgroups. In the case of stronger faultlines, polarization between board members may occur (Fiol et al., 2009), resulting in communication hindrances and decrease in focus on the organization's goals, consequently resulting in decreased board service performance. This is in line with research that studies other origins of faultline emergence in other contexts, but that has consistently linked faultline strength to negative outcomes (Thatcher and Patel, 2012). Indeed, faultline strength is linked to diminished performance outcomes, such as decision-making and group performance (Bezrukova et al., 2009; Rico et al., 2007). Subsequently, we propose the following hypothesis:

H1: Faultine strength is negatively related to board service performance.

\section{Board task conflict as a mediator between faultline strength and board service performance}

While we expect to find a negative relationship between faultline strength and board service performance, in what follows we argue that faultline strength also indirectly affects board service performance through board task conflict.

First, in line with faultline theory, faultline strength can be expected to positively relate to board task conflict. Task conflict refers to differences in viewpoints and opinions about the content of the task (de Wit et al., 2012; Jehn, 1995). Examples of task conflict are conflicts about the distribution of resources, procedures, and policies (De Dreu and Weingart, 2003). We argue that the representation of different stakeholder groups, strengthened by other social category characteristics, on the board will result in different points of view regarding what the tasks of the board are and how these tasks are to be fulfilled. Ashforth and Reingen (2014) discuss 
battles between subgroups and the continuing conflicts in the governance process when decisions must be made, for instance, on the allocation of resources. Therefore, we argue that faultline strength will be positively related to board task conflict, which is in line with studies in other contexts and studying other types of faultline origin, but which have consistently linked faultlines to task conflict (Lau and Murnighan, 2005; Li and Hambrick, 2005).

Second, building on conflict theory, we argue that higher levels of board task conflict are related to decreased board service performance. While the effect of task conflict on group performance is widely studied, the results are inconclusive. For instance, four meta-analyses on the effects of task conflict reveal different results. De Dreu and Weingart (2003) and O'Neill et al. (2013) find that task conflict has a negative effect on group performance, where de Wit et al. (2012) conclude that task conflict is unrelated to such performance. Finally, DeChurch et al. (2013) find that task conflict is positively related to group performance. We build on the argument of De Dreu (2008), which is particularly relevant for our context, to explain why we expect a negative relationship between board task conflict and board service performance. De Dreu (2008) argues that in groups where members have vested interests, task conflict will negatively influence performance. In the same vein, Loughry and Amason (2014) refer to incompatible goals as a possible boundary condition, which can result in lower group performance because of 'political activity', such as competing for resources. As we argue that task conflict in the boards emerges from faultlines originating from the representation of different stakeholder groups, we expect that board members indeed have vested interests and that they will most likely demonstrate political behavior in order to defend the stakeholders they represent. Political activity, such as competing for resources, is detrimental to group performance (De Clercq et al., 2009) as it distracts group members from focusing on the essential tasks and overall goals of the organization (Loughry and Amason, 2014). As such, vested interests and political behavior hinder constructive debate and joint decision-making (De Dreu, 2008). This is further 
in line with findings in the corporate governance literature, negatively linking board task conflict to engagement by the board in advice (Minichilli et al., 2012) and strategic activities (van Ees et al., 2008). Consequently, we offer the following hypothesis:

H2: Board task conflict mediates the relationship between faultline strength and board service performance. Specifically, stronger faultlines are related to higher levels of board task conflict (H2a), in turn negatively related to board service performance (H2b).

\section{Shared organizational goals and subgroup imbalance as moderating factors}

While initial research on faultlines aimed at understanding the impact of faultlines, newer research focuses on understanding contingencies mitigating the negative effects of faultlines (Thatcher and Patel, 2012). In what follows, we address the two sides of the mediation relationship, hereby building on faultlines literature and conflict theory. Specifically, we argue that the level of shared organizational goals will moderate the first part of the mediation in hypothesis 2, whereas subgroup imbalance will moderate the second part of the mediation .

First, we argue that the identification as one group instead of a categorization in subgroups is a key alleviator of the negative impact of faultlines. Specifically, conflict theory indicates that, by introducing 'integrative forces', such as an overarching vision, the conflicts that may arise through subgroup formation can be weakened (Collewaert and Sapienza, 2014; de Wit et al., 2012; Horton et al., 2014). Similarly, Almandoz (2012) and Pache and Santos (2010) indicate that the identification of common goals in the board of directors will make conflict less fierce. This is in line with the faultline literature, where the existence of clear and shared objectives is found to attenuate the negative effects of strong faultlines (van Knippenberg et al., 2011). As such, while stronger faultlines can be expected to lead to higher levels of board task conflict, this effect is likely to be mitigated by higher levels of shared organizational goals. Therefore, 
we propose that higher levels of 'shared organizational goals' among the board members will weaken the positive relationship between faultlines and board task conflict, resulting in the following hypothesis:

H3: Higher levels of shared organizational goals recognized by board members moderates the relationship between faultline strength and board task conflict. Specifically, the positive relationship between faultline strength and board task conflict is mitigated by higher levels of shared organizational goals, and strengthened by lower levels of shared organizational goals.

Second, we argue that the extent to which task conflict leads to decreased performance will be contingent on the relative size of the subgroups. There is a growing interest into how subgroup characteristics influence group performance (Carton and Cummings, 2012; Thatcher and Patel, 2012). Configurational properties, and particularly the size of the subgroups, are studied as potentially important drivers. So far, however, the theoretical arguments and empirical results are inconclusive. Some scholars argue that an imbalanced configuration, in which subgroups are unequally sized, has a positive effect on group performance. The argument put forward here is that the existence of a majority provides certainty (Menon and Phillips, 2011) and makes conflict less overt, resulting in smoother group dynamics, which in turn positively influences performance (Thatcher and Patel, 2012). Other scholars (O'Leary and Mortensen, 2010) find support for the opposite argument: a more balanced configuration positively influences group performance. As they argue, when there is no majority, different subgroup perspectives are equally taken into consideration, resulting in better decisions, which in turn positively influences group performance. Carton and Cummings (2013) add to this stream of literature by arguing that, in order to gain a better understanding of the influence of subgroup imbalance (i.e. the extent to which one subgroup is larger than the other) on group performance, the subgroup 
type also has to be considered. Particularly interesting is that, similar to our study, they study identity-based subgroups, formed by members sharing the same social category characteristics (Carton and Cummings, 2013). Subsequently, when identity-based subgroups arise, subgroup balance negatively influences group performance, which can be attributed to the fact that the overall group gets locked in conflicts related to values and beliefs (Carton and Cummings, 2013). Along the same lines, we can expect increasing levels of subgroup imbalance to weaken the negative effects of task conflict on group performance. Indeed, as the subgroups we study are identity-based, board task conflict will be particularly detrimental to board service performance if subgroups have similar sizes and no dominant subgroup can put its stamp on the discussion. In contrast, increasing subgroup imbalance will mitigate the negative effect of task conflict on board service performance, resulting in the following hypothesis:

H4: The relationship between board task conflict and board service performance is positively moderated by subgroup imbalance. Specifically, higher levels of subgroup imbalance mitigate the negative relationship between board task conflict and board service performance.

\section{METHODS}

\section{Research setting}

Shane and Venkataraman (2000, p. 218) defined the field of entrepreneurship as "the scholarly examination of how, by whom, and with what effects opportunities to create future goods and services are discovered, evaluated, and exploited." Generally, entrepreneurship is about "the new" (in terms of goods, services, knowledge) and how it enters the economic system, as well as about change (Langlois, 2007). An entrepreneurial firm is then either a new firm or a firm somehow willing and able to reset its own memory (Langlois, 2007), and as such entrepreneurship includes, but is not limited to, the creation of new organizations (Shane and 
Venkataraman, 2000). While the term "social entrepreneurship" has since been interpreted in many different ways (Dees, 1998), Mair and Marti (2006, p. 37) bring together the social and entrepreneurial aspects of the concept and define it as a process that involves "the innovative use and combination of resources to pursue opportunities to catalyze social change and/or address social needs." As Mair and Marti (2006) point out, through the social contexts in which social entrepreneurship occur (newly created or established organizations), social enterprises can be distinguished from loosely structured initiatives that also aim at social change, such as activist movements.

It is further clear that the conceptualization of social entrepreneurship is context-dependent (Defourny and Nyssens, 2010). Borzaga and Defourny (2001) and Kerlin (2006) indicate that, in Europe, social entrepreneurship is mainly confined to the realm of work integration and employment creating initiatives. Perrini (2006) indicates that social entrepreneurship in Europe is a non-for-profit response to welfare-related challenges, financial pressure put on socialpurpose organizations and decreased donations to such organizations. As such, "Work Integration Social Enterprises" (hereafter: WISEs), which are the objects of our study, correspond to the definition of social entrepreneurship, while forming a general accepted type of social enterprises in a European context. The primary aim of WISEs is the socio-professional reintegration of disadvantaged people, such as disabled people and people with social or psychological problems, experiencing difficulties to integrate on the job market. WISEs hire these people to produce goods and services for the commercial market. In addition, WISEs invest actively in job training, necessary to make reintegration in the labor market possible, and provide social support to solve personal problems that are often obstacles for employment (Battilana et al., 2015; Pache and Santos, 2013; Van Opstal et al., 2009).

We study WISEs in a specific part of Belgium, namely Flanders. We particularly focus on Flemish organizations for homogeneity reasons as Belgium has a federal structure and social 
economy policies are organized at the regional level. WISEs in Flanders are a good setting to test our theoretical framework for a number of reasons. First, as WISEs lack a dominant stakeholder, their boards of directors commonly consists of different stakeholder representatives (Kerlin, 2006; Spear et al., 2009). The principal stakeholders, namely the beneficiaries and customers, are typically represented on the board. As WISEs generally receive subsidies from the Flemish and local governments, (regional) government representatives frequently serve on WISEs' boards, just like other funders, academics and volunteers. This is in line with the stakeholder groups identified by earlier social entrepreneurship studies (Ebrahim et al., 2014; Pache and Santos, 2010; Ramus and Vaccaro, 2014). As such, the common practice of representation in the board of different stakeholder groups makes WISEs an interesting study context from a stakeholder representation perspective. Second, WISEs face unusual challenges, thus making the engagement of the board in its service role critical and the study of board service performance relevant. Specifically, WISEs must make important strategic decisions on resource allocation. For instance, while their primary social goals point to the allocation of resources to training and counseling of disadvantaged individuals, their commercial goals favor the allocation of resources improving the quality of products and services at a competitive price (Battilana et al., 2015). Further, WISEs operate in highly competitive industries, such as packaging, assembly, gardening, recycling, and printing. Not only are they faced with competition from other WISEs, but also with competition from companies in low-wage countries, production in jails, and other commercial companies. Such challenges require the management and board to apply a risk taking attitude and to act entrepreneurially in the way they work with the beneficiaries as well as in the services and products they offer on the market (Van Opstal et al., 2009). As such, the board can contribute through engaging in service activities that enhance the WISEs' reputation, strengthen the link with the external environment and optimally allocate resources within the organization. 


\section{Sample and data collection}

Data were collected in 2014 from sheltered and social workshops, which are the dominant forms of WISEs in Flanders. In order to construct our sample, we contacted the federation of the sheltered workshops (VLAB) and the federation of the social workshops (SST), having 54 and 94 member organizations, respectively. We asked for the name and email address of the CEO and also, if available, the name and contact details of the board chair.

Our research goals required information from the WISEs, but also from the boards in these organizations. As such, in a first phase, we constructed a short questionnaire, which we distributed over e-mail (subsequently followed up by telephone) to 148 CEOs and 107 board chairs, in which we asked for names and contact information of all board members, as well as some biographical information on these members, and asked them to cooperate in our study. From the initial 148 organizations, 10 WISEs were dropped for technical reasons: mergers, acquisitions or because an enterprise had multiple identification codes despite being only one organization in reality. Ultimately 84 of the remaining 138 enterprises were willing to participate (61\% response rate).

In a second stage, a questionnaire was distributed to the board members (including the board chairs) of the 84 WISEs willing to participate. In addition, a new questionnaire was sent to the CEOs of these organizations. In this questionnaire, we specifically asked questions about board characteristics and tasks alongside questions seeking background information on the organization and its board. The questionnaires were developed in English, translated into Dutch and back-translated to identify any possible confusion or errors that may have resulted from the translation. We pretested the questionnaires with four governance researchers and the directors of the two sectorial federations. Based on their feedback, we made some minor changes. A total of 788 surveys were distributed. After two rounds of reminders and a follow-up by telephone, we received 345 completed surveys ( 79 CEOs and 266 board members) from 80 different social 
enterprises. Because the reliance on the perceptions of a single respondent is a concern in studying board behavior and board dynamics (Huse et al., 2011; Minichilli et al., 2012), our goal was to receive at least two completed questionnaires from every organization. For that reason, we had to exclude one organization for which only one board member participated in the survey. As a result, our analyses are based on 344 completed surveys (response rate 44\%) from 79 organizations (response rate of 57\%).

\section{Measures}

\section{Dependent variable}

Board service performance. In line with Hillman and Dalziel (2003) and Huse (2005), we consider the service role of the board as a combination of advice giving, strategic participation and networking. Based on the research of Minichilli et al. (2009), board service performance is measured using 10 items. The CEO and the board members were asked to indicate on a sevenpoint Likert scale (ranging from 1: strongly disagree to 7: strongly agree) to what extent the board fulfills its service role. More specifically, we asked respondents to indicate the degree to which the board (1) provides advice on management issues; (2) provides advice on financial issues; (3) provides advice on technical issues; (4) provides advice on market issues; (5) provides advice on legal issues; (6) provides linkages to important external stakeholders; (7) provides the firm with external legitimacy and reputation; (8) is involved in promoting strategic initiatives; (9) is involved in taking strategic decisions; and (10) is involved in participating in the implementation phase of long-term strategic decision-making. The Cronbach's alpha of the ten items indicate strong scale reliability (0.91). In a next step, we assessed whether aggregating this variable was justified by calculating the eta-squared statistic $\eta^{2}$. The eta-squared value for this statistic was $0.43(\mathrm{p}<0.001)$, which exceeded the minimum value of 0.20 , demonstrating evidence of interrater consistency (Bezrukova et al., 2009; Li and Hambrick, 2005). The 
individual answers were subsequently aggregated by calculating the mean of board service performance of the respondents belonging to the same organization. Values of board service performance range between 2.3 and 6.66, with an average value of 5.09.

\section{Independent, mediator and moderator variables}

Faultine Strength. To measure faultline strength, we used the faultline algorithm developed by Thatcher et al. (2003), which is one of the most widely used measures of faultline strength (Thatcher and Patel, 2012). Calculating faultline strength (Fau) using this algorithm involves a two-step process. In a first step, the percentage variance explained by attribute alignment of two or more characteristics is measured for all possible splits of the group in two subgroups. The second step is to calculate the maximum value of Fau over all possible splits (Molleman, 2005; Zanutto et al., 2011). Our measure of faultline strength is based on three social category based characteristics: stakeholder group represented, gender and age. These data were collected in the first survey, answered by the CEO or the board chair. As our theoretical rationale is based on stakeholder representation, we first consider which stakeholder group the different board members represent. In doing so, we based our categorization on the identification of represented stakeholder groups in prior social entrepreneurship research (Ebrahim et al., 2014; Pache and Santos, 2010; Ramus and Vaccaro, 2014). As such, the first category we consider are (representatives of) beneficiaries, such as managers of nonprofit organizations in general and institutions taking care of people with disabilities or psychological problems in particular. The second category includes managers of for profit organizations representing market and customer interests. Third, government representatives frequently figure on the board, representing regional and local public policy as well as community interests. Finally, we added a fourth category, the "residual category," consisting of people not belonging to the first three categories, such as academics, appointed to the board to support decision-making, and as such 
not representing a specific stakeholder group. In order for faultlines to emerge, the conceptualization of these different categories should align with other characteristics; as such we added two additional characteristics to calculate faultline strength in the board, namely gender and age. These are social category characteristics frequently used in faultline research as they are clearly visible characteristics, contributing to the emergence of faultlines based on similarity attraction and social identity (Bezrukova et al., 2009; Thatcher and Patel, 2012). In measuring age, three categories are considered $(\leq 40,41-60,>60)$. As to what gender is concerned, we distinguish between men and women. We subsequently calculated Fau using the statistical program R and the asw.cluster package developed by Meyer and Glenz (2013). In our sample, Fau has a value between 0 and 1, with an average value of 0.5 . A Fau value of 1 points to the existence of very strong faultlines, whereas a value close to 0 points to very weak faultlines between subgroups.

Board Task conflict. Board task conflict is measured using 6 items based on Jehn (1994) and Jehn (1995) that are frequently used (Li and Hambrick, 2005; Minichilli et al., 2009; Zona and Zattoni, 2007). Specifically, the respondents were asked to indicate on an seven-point Likert scale (ranging from 1: strongly disagree to 7: strongly agree), the degree to which they agreed with the following statements: On the board (1) there are frequently conflicts and disagreements on decisions to be taken; (2) there are frequently conflicts and disagreements on how the board should work; (3) there are frequently conflicts and disagreements on how to pursue the firm's goal; (4) there are frequently disagreements on the firm's legitimate stakeholders; (5) there is a great deal of disagreement on the decision process; and (6) there are major differences of opinion about executing the strategy.

The board task conflict measure is then the average of 6 items $(\alpha=0.91)$, aggregated by taking the mean for the respondents belonging to the same organization $\left(\eta^{2}=0.39, p<0.001\right)$. Values for board task conflict range between 1 and 2.94, with an average value of 1.70 . 
Shared organizational goals. The level of shared organizational goals was assessed using the scale of Leana and Pil (2006), adapted to a board context by Fredette and Bradshaw (2012). Respondents were asked to indicate the degree to which they agreed with six statements using a seven-point Likert scale (1: strongly disagree; 7: strongly agree). The six items are the following: (1) Board members share the same ambitions and vision for the organization; (2) Board members are enthusiastic about pursuing the collective goals and mission of the organization; (3) There is a commonality of purpose in the board of my organization; (4) Board members are committed to the goals of the organization; (5) Board members view themselves as partners in charting the overall direction of the organization; and (6) On the board, everyone is in total agreement on our organization's vision. Responses to the items were aggregated among members of the same organization $\left(\alpha=0.94 ; \eta^{2}=0.45, p<0.001\right)$. The variable's value ranges between 3 and 6.89, with an average of 5.89 .

Subgroup imbalance. As noted earlier, the Fau algorithm calculates for which split into two subgroups the value of faultline strength is maximized. As such, through the calculation of Fau, we also gained insight into the size of subgroups. We subsequently calculated subgroup imbalance by dividing the size of the largest board subgroup by total board size (in terms of board members). Thus, a value of 0.5 indicates that both subgroups have the same size, which can be considered as a perfect subgroup balance. A value closer to 1 indicates that the subgroups are increasingly unequally sized, resulting in increasing subgroup imbalance. The average value for subgroup balance in our sample is 0.66 .

\section{Control variables}

We further added control variables at board and firm level that may affect board service performance (Minichilli et al., 2012; Zona and Zattoni, 2007). At the board level, we control for the frequency of board meetings, as research finds that the frequency of board meetings 
impacts board service performance (Knockaert and Ucbasaran, 2013). Because each board member may bring different linkages and resources to the board, the number of board members is also expected to influence board service performance (Knockaert and Ucbasaran, 2013; Minichilli et al., 2009). The organizations in our sample on average hold about 6 board meetings per year, with a minimum of 2 and a maximum of 12 annual board meetings. Board size ranges from 3 to 20 board members, with an average board size of about 9 members. In line with prior faultline research, we further control for diversity effects in the board (Lau and Murnighan, 2005; Li and Hambrick, 2005). We used Blau's (1977) heterogeneity index to measure board diversity in terms of stakeholder representation, age and gender. Following the procedure suggested by Jehn et al. (1999), we averaged the heterogeneity indices for these three indicators to construct the board heterogeneity control variable (Bezrukova et al., 2009; Bezrukova et al., 2012; Veltrop et al., 2015). In our sample, board heterogeneity ranges from 0 to 0.57 , with an average value of 0.39 .

At the organizational level, we controlled for age and size of the social enterprise as the need for advice and establishing legitimacy by board members may vary between younger and older organizations and between smaller and larger organizations (Knockaert et al., 2015; Minichilli et al., 2012). The size of the organization is operationalized as the number of employees at the end of 2013, obtained from the public annual accounting database, Belfirst. The organizations in our sample are between 11 and 54 years old, with an average age of 25 . The number of employees ranges from 12 to 585 with an average of 142 employees.

\section{RESULTS}

Table I provides the means, standard deviations and correlations for all variables. 
To test our model as depicted in Figure 1, we employed a regression-based path analysis hereby building on existing computational tools. Variance inflation factors (VIFs) ranged between 1.157 and 2.679, indicating that multicollinearity is not a problem in our analyses (Hair et al., 2006). We used the PROCESS macro for SPSS developed by Hayes (2013), which allows for testing for the total effect of faultline strength on board service performance (hypothesis 1), as well as for the mediation effect through board task conflict (hypothesis 2) (Hayes and Scharkow, 2013). Furthermore, we used this macro to test for the moderating effects of shared organizational goals (hypothesis 3) and subgroup imbalance (hypothesis 4).

The model in path diagram can be found in Figure 2 and consists of three distinct submodels. Model 1, in Panel A, is used to test whether faultline strength has an effect on board service performance (hypothesis 1). Models 2 and 3, in Panel B, are used to estimate the indirect effect of faultline strength on board service performance through board task conflict (hypothesis 2). Models 4 and 5 in panel $\mathrm{C}$ are used to test hypothesis 3 and 4.

INSERT FIGURE 2 ABOUT HERE

The results of our analysis are presented in Table II. First, the control model only contains the control variables. The results show that the frequency of board meetings has a significantly positive effect on board service performance $(B=0.860, \mathrm{p}<0.001)$. Model 1 then allows us to estimate the total effect (c in Panel A of Figure 2) of faultline strength on board service performance. We find a significant, negative effect $(\mathrm{B}=-1.360, \mathrm{p}<0.01)$, supporting hypothesis 1. In Model 2 and Model 3, this total effect is decomposed in a direct (c' in Panel B of Figure 2) and an indirect effect (a en b in Panel B of Figure 2). We find a significant, negative direct effect of faultline strength on board service performance $(\mathrm{B}=-1.006, \mathrm{p}<0.05)$. 
Furthermore, the results show a significantly positive effect of faultline strength on board task conflict $(\mathrm{B}=0.727, \mathrm{p}<0.05)$ and a significant negative effect of board task conflict on board service performance $(B=-0.487, \mathrm{p}<0.01)$. A $95 \%$ confidence interval for this indirect effect, based on 10,000 bootstrap samples, was found to range between -0.920 and -0.069 . As zero is not included in the interval, board task conflict can be construed as a mediator between faultline strength and board service performance, in the expected directions, thus supporting hypotheses $2 \mathrm{a}$ and $2 \mathrm{~b}$. Next, in model 4 , the moderation effect of shared organizational goals is tested ( $\mathrm{d}$ in Panel $\mathrm{C}$ of Figure 2). We find a significant, negative effect $(\mathrm{B}=-1.577, \mathrm{p}<0.01)$, indicating that higher levels of shared organizational goals attenuate the positive effect of faultline strength on board task conflict, resulting in lower levels of board task conflict. As such we find support for hypothesis 3. Finally in model 5, we test whether the effect of board task conflict on board service performance is moderated by subgroup imbalance (e in Panel $\mathrm{C}$ of Figure 2). Hypothesis 4 is not supported as we find a moderating effect that is not statistically significant.

INSERT TABLE II ABOUT HERE

In order to interpret the significant interaction between faultline strength and shared organizational goals in explaining board task conflict, we visualized the interaction in Figure 3. The figure demonstrates that the slope of faultline strength is steeper for organizations with lower levels of shared organizational goals. Furthermore, the effect of faultline strength on board task conflict is neutralized for organizations with high levels of shared organizational goals, emphasizing the importance of having a shared vision on what the goals of the organization are within the board.

INSERT FIGURE 3 ABOUT HERE 


\section{DISCUSSION AND IMPLICATIONS}

Stakeholder democracy in general, and stakeholder representation in the board of directors specifically, can help organizations to deal with the growing attention to sustainability and corporate citizenship. Through the involvement of stakeholders in the board, it is expected that organizations will be better able to balance diverging stakeholder expectations and, consequently, gain legitimacy from different stakeholder groups, which might be important for resource acquisition. Despite these advantages of stakeholder representation, several authors also warn for the potentially negative effects of such representation. In this study, we argue that stakeholder representation may give rise to the origination of subgroups and related faultlines. Particularly, we find that faultline strength is positively associated with lower levels of board service performance and that this relationship is mediated by board task conflict. As such, our results show the importance of considering, alongside the presumed positive implications of the representation of stakeholder groups in the board, the potentially dark side of such stakeholder representation. However, our research also points to the existence of important contingencies that may mitigate such reverse effects. In particular, we find that, as board members' visions on firm's organizational goals increasingly converge, the negative impact of faultline strength on conflict within the board is mitigated. While not explicitly the focus of this study, we contend that the board chair, often considered a mediating hierarch in resolving decision-making ambiguities (Knockaert et al., 2015), may have an important role to play in enhancing convergence of board members' visions on the organizational goals. Further, while we expected subgroup imbalance to alleviate the negative relationship between task conflict within the board and board service performance, we did not find support for such relationship. While our expectations were warranted following conflict theory, developments in the organizational behavior and entrepreneurship literatures may provide indications to explanations for the lack of support. Specifically, researchers point to the fact that individual and group behavior may 
not only be driven by objectives states, but may also be related to the perception of such states. For instance, in studies on diversity, scholars argue that it is not only the actual degree of diversity that affects behavior, but that the perceived dissimilarity between group members may also matter (Cunningham, 2007; Knockaert et al., 2015). Similarly, subgroup imbalance may only impact behavior if such imbalance is also perceived by the other group members (Cronin et al., 2011; O'Leary and Mortensen, 2010). Alternatively, subgroup imbalance may only alleviate the negative consequences of board task conflict in cases where such imbalance also leads to differences in the power distribution between subgroups.

Our study contributes to the literature in a number of ways. First, it contributes to the literature on stakeholder democracy and stakeholder participation, which has largely considered stakeholder representation in the board a good practice (Harrison and Freeman, 2004; Moriarty, 2014), but neglects to study the phenomenon in general. Specifically, it points to the potentially nefarious implications of such representation, alongside the identification of contingency factors that may alleviate such implications. Second, our study adds to the corporate governance literature, which calls for an increased interest in the board service role, alongside (behavioral) theoretical perspectives that help to understand the board's engagement in this role. Indeed, our approach is a clear shift away from the agency perspective that has dominated governance research for decades (Daily et al., 2003; McDonald and Westphal, 2010). Our results point to the importance of faultlines and conflict, and their underpinning theories, in studying board functioning. As such, it also responds to calls to leave the beaten paths of board structure and composition in order to provide deeper insights into board dynamics (Finkelstein and Mooney, 2003; Huse, 2007). Finally, our study contributes to faultlines literature, elaborating on the concept in a board context, in which it has been understudied. Specifically, it supports Lim et al. (2013)'s call to push the boundaries of the faultlines concept by not only considering multiple demographic attributes. Specifically, it introduces stakeholder representation as an 
important identity-based attribute. As such, it also responds to calls in the entrepreneurship literature to integrate the promising concept of faultlines in entrepreneurial settings (Lim et al., 2013).

Our study also has implications for practitioners as our results reveal the potentially negative effects of stakeholder representation. Managers of organizations, just like their stakeholders and board members, should be aware of the potential drawbacks of representation of stakeholder groups in the board. While this should not be misinterpreted as a call to compose uniform boards in terms of stakeholder representation and other demographic characteristics, this research indicates that it is important to be aware of the potentially negative effects of faultlines and subgroup formation. At the same time, our study points to the importance of contingency factors, such as alignment between board members as to what the organizational goals are, in alleviating the negative consequences of strong faultline emergence. Practitioners who follow good ethical practices by incorporating a range of stakeholders in the board of directors may want to take such contingencies into consideration.

Our paper also has some limitations, which have implications for future research. First, in line with the majority of governance research, our study is based on a cross-sectional design, and is as such unable to identify causal relationships. Longitudinal studies may provide additional insights into causal relationships between subgroup and faultline emergence, the efforts made to attenuate the negative effects of faultlines, and board performance (Machold and Farquhar, 2013). Additionally, qualitative research designs could be employed in order to study "how" and "why" questions, thus further opening up the black box of board dynamics in order to shed light on the processes through which different types of conflicts and actions for mitigating the drawbacks from strong faultlines work (McNulty et al., 2013). Such alternative research designs could include, among others, observation of board meetings and focus groups (Beck, 2014; Bezemer et al., 2014; Hough et al., 2014; Van der Brempt et al., 2015). 
Second, as articulated above, future research could study the impact of subgroup imbalance in alleviating the negative consequences of board task conflict on board performance. For instance, future research could simultaneously examine actual and perceived subgroup imbalance. It has to be noted that, in order to do so, ideally, two-staged research designs will have to be developed, in which the researcher first collects data in order to calculate faultline existence and strength. In a second phase, the researcher will then have to confront group members with the identified subgroups, and ask group members to indicate the extent to which imbalance between such subgroups is also perceived. Or, future research may revert to experimental designs to shed further light on the relationship between actual and perceived subgroup imbalance. Alternatively, future research could study the relationship between subgroup imbalance and different dimensions of power (Triana et al., 2014) and how these dimensions could alleviate or strengthen the nefarious implications of strong faultlines. Finally, as our results show that it is important to build a shared vision of what the goals of the organization are, future research could provide insight into the antecedents of convergence in shared organizational goals. Specifically, board development practices, such as team building and board evaluations, may contribute to such a shared vision (Gill et al., 2005; Kiel and Nicholson, 2005) and may be fruitful research areas. Further, in line with board leadership research, board chairs may also facilitate a consensus on what the organizational goals are (Harrison et al., 2013) and future research could purposefully investigate under which circumstances (such as communication style, types and intensity of interactions, leadership style...) board chairs are successful in building such consensus.

\section{CONCLUSIONS}

In summary, this study is the first to study how faultlines originating from the representation of different stakeholder groups are related to board functioning. We conducted this study in the 
especially relevant context of social enterprises. Specifically, it points to the existence of a negative relationship between faultline strength and board service performance, which is mediated by board task conflict. Furthermore, the association between faultline strength and board task conflict was attenuated by a convergence between board members over organizational goals. Our study points to important implications for both academia and practice. 


\section{REFERENCES}

Aguinis, H. and Glavas, A. (2012). 'What We Know and Don't Know About Corporate Social Responsibility: A Review and Research Agenda'. Journal of Management, 38, 932-968.

Almandoz, J. (2012). 'Arriving at the starting line: the impact of community and financial logics on new banking ventures'. Academy of Management Journal, 55, 1381-1406.

Almandoz, J. (2014). 'Founding Teams as Carriers of Competing Logics: When Institutional Forces Predict Banks' Risk Exposure'. Administrative Science Quarterly, 59, 442-473.

Ashforth, B. E. and Reingen, P. H. (2014). 'Functions of Dysfunction: Managing the Dynamics of an Organizational Duality in a Natural Food Cooperative'. Administrative Science Quarterly, 59, 474-516.

Battilana, J. and Lee, M. (2014). 'Advancing Research on Hybrid Organizing - Insights from the Study of Social Enterprises'. Academy of Management Annals, 8, 397-441.

Battilana, J., Sngul, M., Pache, A.-C. and Model, J. (2015). 'Harnessing productive tensions in hybrid organizations: the case of work integration social enterprises.'. Academy of Management Journal, 58, 1658-1858.

Beck, D. B. (2014). 'Learning to be, learning about. A socio-cultural learning approach to board practice'. In: Cornforth, C. and Brown, W. A. (Eds), Nonprofit governance, innovative perspectives and approaches. Abingdon: Routledge, 103-122.

Bezemer, P.-J., Nicholson, G. and Pugliese, A. (2014). 'Inside the boardroom: exploring board member interactions'. Qualitative Research in Accounting and Management, 11, 238-259.

Bezrukova, K., Jehn, K. A., Zanutto, E. L. and Thatcher, S. M. B. (2009). 'Do Workgroup Faultlines Help or Hurt? A Moderated Model of Faultlines, Team Identification, and Group Performance'. Organization Science, 20, 35-50.

Bezrukova, K., Thatcher, S. M. B., Jehn, K. A. and Spell, C. S. (2012). 'The Effects of Alignments: Examining Group Faultlines, Organizational Cultures, and Performance'. Journal of Applied Psychology, 97, 77-92.

Blau, P. (1977). Inequality and Composition: a Primitive Theory of Social Structure. New York: Free Press.

Borzaga, C. and Defourny, J. (2001). 'Conclusions: Social enterprises in Europe: A diversity of initiatives and prospects'. In: Borzaga, C. and Defourny, J. (Eds), The emergence of social enterprise. Londen, New York: Routledge, 350-370.

Carroll, A. B. (2015). 'Corporate social responsibility: The centerpiece of competing and complementary frameworks'. Organizational Dynamics, 44, 87-96.

Carton, A. M. and Cummings, J. N. (2012). 'A Theory of Subgroups in Work Teams'. Academy of Management Review, 37, 441-470.

Carton, A. M. and Cummings, J. N. (2013). 'The Impact of Subgroup Type and Subgroup Configurational Properties on Work Team Performance'. Journal of Applied Psychology, 98, 732-758.

Collewaert, V. and Sapienza, H. J. (2014). 'How Does Angel Investor-Entrepreneur Conflict Affect Venture Innovation? It Depends'. Entrepreneurship Theory and Practice, doi: 10.1111/etap.12131.

Cornforth, C. (2012). 'Nonprofit Governance Research: Limitations of the Focus on Boards and Suggestions for New Directions'. Nonprofit and Voluntary Sector Quarterly, 41, 1116-1135.

Cronin, M. A., Bezrukova, K., Weingart, L. R. and Tinsley, C. H. (2011). 'Subgroups within a team: The role of cognitive and affective integration'. Journal of Organizational Behavior, 32, 831-849.

Cunningham, G. (2007). 'Perceptions As Reality: The Influence of Actual and Perceived Demographic Dissimilarity'. Journal of Business \& Psychology, 22, 79-89.

Daily, C. M., Dalton, D. R. and Cannella, A. A. (2003). 'Corporate Governance: Decades of Dialogue and Data'. The Academy of Management Review, 28, 371-382. 
De Clercq, D., Menguc, B. and Auh, S. (2009). 'Unpacking the relationship between an innovation strategy and firm performance: The role of task conflict and political activity'. Journal of Business Research, 62, 1046-1053.

De Dreu, C. K. W. (2008). 'The virtue and vice of workplace conflict: food for (pessimistic) thought'. Journal of Organizational Behavior, 29, 5-18.

De Dreu, C. K. W. and Weingart, L. R. (2003). 'Task versus relationship conflict, team performance, and team member satisfaction: A meta-analysis'. Journal of Applied Psychology, 88, 741-749.

de Wit, F. R. C., Greer, L. L. and Jehn, K. A. (2012). 'The Paradox of Intragroup Conflict: A MetaAnalysis'. Journal of Applied Psychology, 97, 360-390.

DeChurch, L. A., Mesmer-Magnus, J. R. and Doty, D. (2013). 'Moving Beyond Relationship and Task Conflict: Toward a Process-State Perspective'. Journal of Applied Psychology, 98, 559-578.

Dees, J. G. (1998). 'The meaning of social entrepreneurship'. doi. Available at https://csistg.gsb.stanford.edu/sites/csi.gsb.stanford.edu/files/TheMeaningofsocialEntrepre neurship.pdf

Defourny, J. and Nyssens, M. (2010). 'Conceptions of Social Enterprise and Social Entrepreneurship in Europe and the United States: Convergences and Divergences'. Journal of Social Entrepreneurship, 1, 32-53.

Diochon, M. C. (2010). 'Governance, entrepreneurship and effectiveness: exploring the link'. Social Enterprise Journal, 6, 93-109.

Doherty, B., Haugh, H. and Lyon, F. (2014). 'Social Enterprises as Hybrid Organizations: A Review and Research Agenda'. International Journal of Management Reviews, 16, 417-436.

Ebrahim, A., Battilana, J. and Mair, J. (2014). 'The governance of social enterprises: Mission drift and accountability challenges in hybrid organizations'. Research in Organizational Behavior, 34, 81-100.

Ebrahim, A. and Rangan, V. K. (2014). 'What Impact? A framework for measuring the scale and scop of social performance.'. California Management Review, 56, 118-141.

Evan, W. M. and Freeman, R. E. (1993). 'A stakeholder theory of the modern corporation: Kantian capitalism'. In: Hoffman, W. M. and Frederick, R. E. (Eds), Business Ethics: Readings and Cases in Corporate Morality. 3rd ed. New York: McGraw-Hill, 145-154.

Fiegener, M. K. (2005). 'Determinants of board participation in the strategic decisions of small corporations'. Entrepreneurship Theory and Practice, 29, 627-650.

Finkelstein, S. and Mooney, A. C. (2003). 'Not the usual suspects: How to use board process to make boards better'. Academy of Management Executive, 17, 101-113.

Fiol, C. M., Pratt, M. G. and O'Connor, E. J. (2009). 'Managing intractable identity conflicts'. Academy of Management Review, 34, 32-55.

Forbes, D. P. and Milliken, F. J. (1999). 'Cognition and Corporate Governance: Understanding boards of directors as strategic decision-making groups'. Academy of Management Review, 24, 489505.

Fredette, C. and Bradshaw, P. (2012). 'Social capital and nonprofit governance effectiveness'. Nonprofit Management \& Leadership, 22, 391-409.

Gill, M., Flynn, R. J. and Reissing, E. (2005). 'The governance self-assessment checklist: An instrument for assessing board effectiveness'. Nonprofit Management and Leadership, 15, 271-294.

Hair, J. F., Black, W. C., Babin, B. J. and Anderson, R. E. (2006). Multivariate Data Analysis. Upper Saddle River NJ: Pearson.

Hambrick, D. C., Werder, A. v. and Zajac, E. J. (2008). 'New Directions in Corporate Governance Research'. Organization Science, 19, 381-385.

Harrison, D. A. and Klein, K. J. (2007). 'What's the difference? Diversity constructs as separation, variety, or disparity in organizations'. Academy of Management Review, 32, 1199-1228.

Harrison, J. S. and Freeman, R. E. (2004). 'Special topic: Democracy in and around organizations'. Academy of Management Executive, 18, 49-53.

Harrison, Y., Murray, V. and Cornforth, C. (2013). 'Perceptions of Board Chair Leadership Effectiveness in Nonprofit and Voluntary Sector Organizations'. Voluntas, 24, 688-712. 
Hayes, A. F. (2013). An introduction to mediation, moderation, and conditional process analysis: a regression-based approach. New York: Guilford Press.

Hayes, A. F. and Scharkow, M. (2013). 'The Relative Trustworthiness of Inferential Tests of the Indirect Effect in Statistical Mediation Analysis: Does Method Really Matter?'. Psychological Science, 24, 1918-1927.

Hendry, J. (2001). 'Missing the target: normative stakeholder theory and the corporate governance debate'. Business Ethics Quarterly, 11, 159-176.

Hielscher, S., Beckmann, M. and Pies, I. (2014). 'Participation versus Consent: Should Corporations Be Run according to Democratic Principles?'. Business Ethics Quarterly, 24, 533-563.

Hillman, A., J. and Dalziel, T. (2003). 'Boards of Directors and Firm Performance: Integrating Agency and Resource Dependence Perspectives'. The Academy of Management Review, 28, 383396.

Horton, K. E., Bayerl, P. S. and Jacobs, G. (2014). 'Identity conflicts at work: An integrative framework'. Journal of Organizational Behavior, 35, S6-22.

Hough, A., McGregor-Lowndes, M. and Ryan, C. (2014). 'Board monitoring and judgement as processes of sensemaking'. In: Cornforth, C. and Brown, W. A. (Eds), Nonprofit governance, innovative perspectives and approaches. Abingdon: Routledge,

Huse, M. (2005). 'Accountability and Creating Accountability: a Framework for Exploring Behavioural Perspectives of Corporate Governance'. British Journal of Management, 16, 65-79.

Huse, M. (2007). Boards, governance and value creation. Cambridge: University Press.

Huse, M., Hoskisson, R., Zattoni, A. and Vigano, R. (2011). 'New Perspectives on Board Research: Changing the Research Agenda'. Journal of Management and Governance, 15, 5-28.

Huybrechts, B. (2010). 'The governance of fair trade social enterprises in Belgium'. Social Enterprise Journal, 6, 110-124.

Jehn, K. A. (1994). 'Enhancing effectiveness - an investigation of advantages and disadvantages of value-based intragroup conflict'. International Journal of Conflict Management, 5, 223-238.

Jehn, K. A. (1995). 'A Multimethod Examination of the Benefits and Detriments of Intragroup Conflict'. Administrative Science Quarterly, 40, 256-282.

Jehn, K. A., Northcraft, G. B. and Neale, M. A. (1999). 'Why differences make a difference: A field study of diversity, conflict, and performance in workgroups'. Administrative Science Quarterly, 44, 741-763.

Kaczmarek, S., Kimino, S. and Pye, A. (2012). 'Board Task-related Faultlines and Firm Performance: A Decade of Evidence'. Corporate Governance: An International Review, 20, 337-351.

Kerlin, J. A. (2006). 'Social Enterprise in the United States and Europe: Understanding and Learning from the Differences'. Voluntas, 17, 246-262.

Kiel, G. C. and Nicholson, G. J. (2005). 'Evaluating Boards and Directors'. Corporate Governance: An International Review, 13, 613-631.

Knockaert, M., Bjornali, E. S. and Erikson, T. (2015). 'Joining forces: Top management team and board chair characteristics as antecedents of board service involvement'. Journal of Business Venturing, 30, 420-435.

Knockaert, M. and Ucbasaran, D. (2013). 'The Service Role of Outside Boards in High Tech Start-ups: A Resource Dependency Perspective'. British Journal of Management, 24, 69-84.

Langlois, R. N. (2007). 'The entrepreneurial theory of the firm and the theory of the entrepreneurial firm'. Journal of Management Studies, 44, 1107-1124.

Lau, D. C. and Murnighan, J. K. (1998). 'Demographic diversity and faultlines: the compositional dynamics of organizational groups'. Academy of Management Review, 23, 325-340.

Lau, D. C. and Murnighan, J. K. (2005). 'Interactions within groups and subgroups: the effects of demographic faultlines'. Academy of Management Journal, 48, 645-659.

Leana, C. R. and Pil, F. K. (2006). 'Social Capital and Organizational Performance: Evidence from Urban Public Schools'. Organization Science, 17, 353-366.

Li, J. and Hambrick, D. C. (2005). 'Factional groups: a new vantage on demographic faultlines, conflict, and disintegration in work teams'. Academy of Management Journal, 48, 794-813. 
Lim, J. Y. K., Busenitz, L. W. and Chidambaram, L. (2013). 'New Venture Teams and the Quality of Business Opportunities Identified: Faultlines Between Subgroups of Founders and Investors'. Entrepreneurship Theory and Practice, 37, 47-67.

Loughry, M. L. and Amason, A. (2014). 'Why won't task conflict cooperate? Deciphering stubborn results'. International Journal of Conflict Management, 25, 333-358.

Machold, S. and Farquhar, S. (2013). 'Board Task Evolution: A Longitudinal Field Study in the UK'. Corporate Governance: An International Review, 21, 147-164.

Mair, J. and Marti, I. (2006). 'Social entrepreneurship research: A source of explanation, prediction, and delight'. Journal of World Business, 41, 36-44.

Mair, J., Mayer, J. and Lutz, E. (2015). 'Navigating Institutional Plurality: Organizational Governance in Hybrid Organizations'. Organization Studies, 36, 713-739.

Matten, D. and Crane, A. (2005). 'What is stakeholder democracy? Perspectives and issues'. Business Ethics: A European Review, 14, 6-13.

McDonald, M. L. and Westphal, J. D. (2010). ' A little help here? Board control, CEO identification with the corporate elite, and strategic help provided to CEO's at other firms'. Academy of Management Journal, 53, 343-370.

McNulty, T., Zattoni, A. and Douglas, T. (2013). 'Developing Corporate Governance Research through Qualitative Methods: A Review of Previous Studies'. Corporate Governance: An International Review, 21, 183-198.

Menon, T. and Phillips, K. W. (2011). 'Getting Even or Being at Odds? Cohesion in Even- and OddSized Small Groups'. Organization Science, 22, 738-753.

Meyer, B. and Glenz, A. (2013). 'Team Faultline Measures: A Computational Comparison and a New Approach to Multiple Subgroups'. Organizational Research Methods, 16, 393-424.

Miller, T. L., Grimes, M. G., McMullen, J. S. and Vogus, T. J. (2012). 'Venturing for others with heart and head: how compassion encourages social entrepreneurship'. Academy of Management Review, 37, 616-640.

Minichilli, A., Zattoni, A., Nielsen, S. and Huse, M. (2012). 'Board task performance: An exploration of micro-and macro-level determinants of board effectiveness'. Journal of Organizational Behavior, 33, 193-215.

Minichilli, A., Zattoni, A. and Zona, F. (2009). 'Making Boards Effective: An Empirical Examination of Board Task Performance'. British Journal of Management, 20, 55-74.

Molleman, E. (2005). 'Diversity in Demographic Characteristics, Abilities and Personality Traits: Do Faultlines Affect Team Functioning?'. Group Decision and Negotiation, 14, 173-193.

Moriarty, J. (2010). 'Participation in the Workplace: Are Employees Special?'. Journal of Business Ethics, 92, 373-384.

Moriarty, J. (2014). 'The Connection Between Stakeholder Theory and Stakeholder Democracy: An Excavation and Defense'. Business \& Society, 53, 820-852.

O'Dwyer, B. (2005). 'Stakeholder democracy: challenges and contributions from social accounting'. Business Ethics: A European Review, 14, 28-41.

O'Leary, M. B. and Mortensen, M. (2010). 'Go (Con)figure: Subgroups, Imbalance, and Isolates in Geographically Dispersed Teams'. Organization Science, 21, 115-131.

O'Neill, T. A., Allen, N. J. and Hastings, S. E. (2013). 'Examining the "Pros" and "Cons" of Team Conflict: A Team-Level Meta-Analysis of Task, Relationship, and Process Conflict'. Human Performance, 26, 236-260.

Okhmatovskiy, I. and David, R. J. (2012). 'Setting Your Own Standards: Internal Corporate Governance Codes as a Response to Institutional Pressure'. Organization Science, 23, 155-176.

Ostrower, F. and Stone, M. M. (2006). 'Governance: Research trends, gaps, and future prospects.'. In: Powell, W. W. and Steinberg, R. (Eds), The nonprofit sector: A research handbook. 2nd ed. New Haven, CT: Yale University Press, 612-628.

Ostrower, F. and Stone, M. M. (2010). 'Moving Governance Research Forward: A Contingency-Based Framework and Data Application'. Nonprofit and Voluntary Sector Quarterly, 39, 901-924. 
Pache, A.-C. and Santos, F. (2010). 'When worlds collide: the internal dynamics of organizational responses to conflicting institutional demands'. Academy of Management Review, 35, 455476.

Pache, A.-C. and Santos, F. (2013). 'Inside the hybrid organization: selective coupling as response to conflicting institutional logics'. Academy of Management Journal, 56, 972-1001.

Perrini, F. (2006). The new social entrepreneurship: what awaits social entrepreneurial ventures? Cheltenham, UK: Edward Elgar Publishing.

Ramus, T. and Vaccaro, A. (2014). 'Stakeholders Matter: How Social Enterprises Address Mission Drift'. Journal of Business Ethics, doi: 10.1007/s10551-014-2353-y.

Rico, R., Molleman, E., Sanchez-Manzanares, M. and Vegt, G. S. V. d. (2007). 'The Effects of Diversity Faultlines and Team Task Autonomy on Decision Quality and Social Integration'. Journal of Management, 33, 111-132.

Shane, S. and Venkataraman, S. (2000). 'The promise of entrepreneurship as a field of research'. Academy of Management Review, 25, 217-226.

Smith, S. R. (2010). 'Hybridization and nonprofit organizations: The governance challenge'. Policy and Society, 29, 219-229.

Smith, W. K., Gonin, M. and Besharov, M. L. (2013). 'Managing Social-Business Tensions: A Review and Research Agenda for Social Enterprise'. Business Ethics Quarterly, 23, 407-442.

Spear, R., Cornforth, C. and Aiken, M. (2009). 'The governance challenges of social enterprises: evidence from a UK empirical study.'. Annals of Public \& Cooperative Economics, 80, 247273.

Thatcher, S. M. B., Jehn, K. A. and Zanutto, E. (2003). 'Cracks in Diversity Research: The Effects of Diversity Faultlines on Conflict and Performance'. Group Decision and Negotiation, 12, $217-$ 241.

Thatcher, S. M. B. and Patel, P. C. (2012). 'Group Faultlines: A Review, Integration, and Guide to Future Research'. Journal of Management, 38, 969-1009.

Timming, A. R. (2015). 'The "reach' of employee participation in decision-making: exploring the Aristotelian roots of workplace democracy'. Human Resource Management Journal, 25, 382396.

Triana, M. d. C., Miller, T. L. and Trzebiatowski, T. M. (2014). 'The Double-Edged Nature of Board Gender Diversity: Diversity, Firm Performance, and the Power of Women Directors as Predictors of Strategic Change'. Organization Science, 25, 609-632.

Tuggle, C. S., Schnatterly, K. and Johnson, R. A. (2010). 'Attention patterns in the boardroom: how board composition and processes affect discussion of entrepreneurial issues'. Academy of Management Journal, 53, 550-571.

Van Buren III, H. J. (2010). 'Taking (and Sharing Power): How Boards of Directors Can Bring About Greater Fairness for Dependent Stakeholders'. Business \& Society Review 115, 205-230.

Van der Brempt, O., Boone, C., van Witteloostuijn, A. and van den Berg, A. (2015). 'Toward a behavioural theory of cooperation between managers and employee representatives in works councils'. Economic and Industrial Democracy, doi: 10.1177/0143831x15578721.

Van Ees, H., Gabrielsson, J. and Huse, M. (2009). 'Toward a Behavioral Theory of Boards and Corporate Governance'. Corporate Governance: An International Review, 17, 307-319.

van Ees, H., van der Laan, G. and Postma, T. J. B. M. (2008). 'Effective board behavior in The Netherlands'. European Management Journal, 26, 84-93.

van Knippenberg, D., Dawson, J. F., West, M. A. and Homan, A. C. (2011). 'Diversity faultlines, shared objectives, and top management team performance'. Human Relations, 64, 307-336.

Van Opstal, W., Deraedt, E. and Gijselinckx, C. (2009). 'Monitoring profile shifts and differences among WISEs in Flanders'. Social Enterprise Journal, 5, 229-258.

Veltrop, D. B., Hermes, N., Postma, T. and de Haan, J. (2015). 'A Tale of Two Factions: Why and When Factional Demographic Faultlines Hurt Board Performance'. Corporate Governance: An International Review, 23, 145-160. 
Westphal, J. D. and Zajac, E. J. (2013). 'A Behavioral Theory of Corporate Governance: Explicating the Mechanisms of Socially Situated and Socially Constituted Agency'. Academy of Management Annals, 7, 607-661.

Zahra, S. A. and Pearce, J. A. (1989). 'Boards of directors and corporate financial performance - a review and integrative model'. Journal of Management, 15, 291-334.

Zanutto, E., Bezrukova, K. and Jehn, K. (2011). 'Revisiting faultline conceptualization: measuring faultline strength and distance'. Quality \& Quantity, 45, 701-714.

Zona, F. and Zattoni, A. (2007). 'Beyond the Black Box of Demography: board processes and task effectiveness within Italian firms'. Corporate Governance: An International Review, 15, 852 864. 
FIGURE 1

Conceptual model

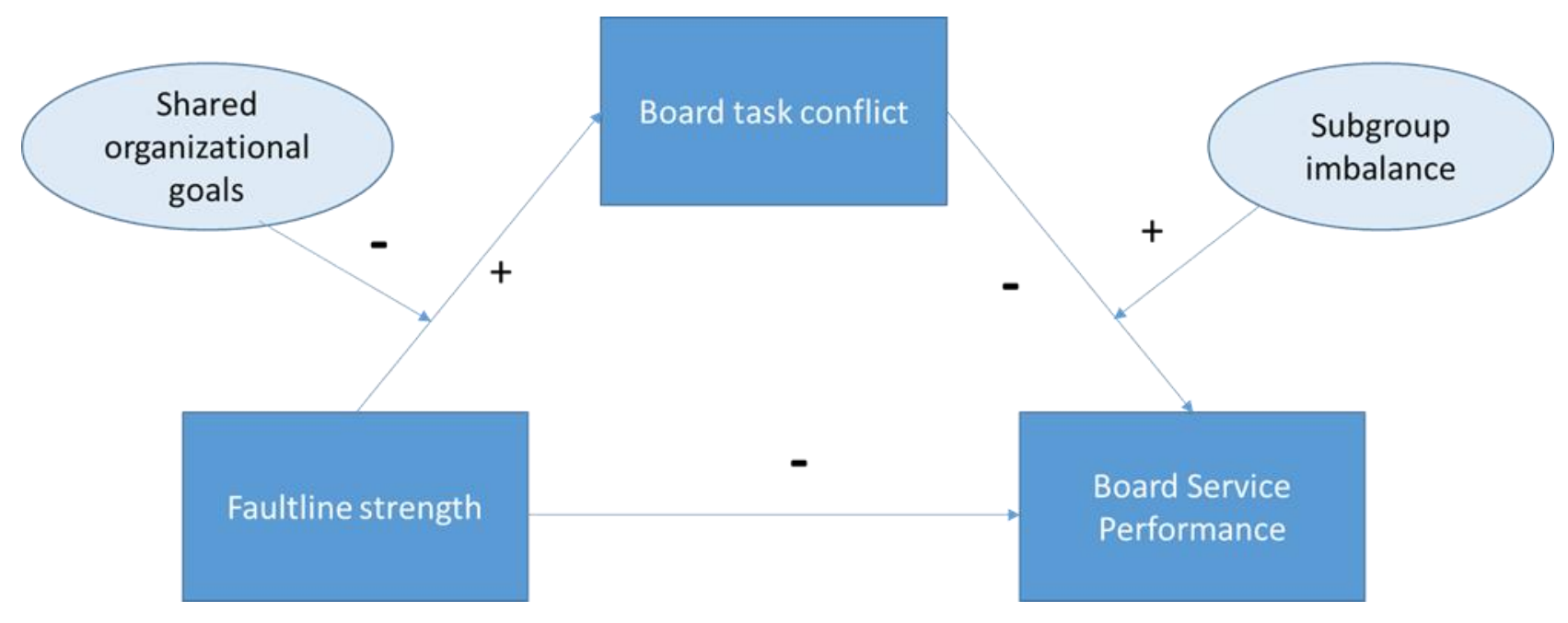


FIGURE 2

Conceptual Model (Figure 1) represented as a path model, referring to the regression coefficients estimated and reported in Table 2

Panel A

Faultline Strength
MODEL 1

Board

Service Performance

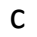

b

Board

Service Performance

$C^{\prime}$

\section{MODEL 4}

Panel C

Shared Organizational Goals $X$

Fautline Strength
Board Task Conflict

\section{d}

Faultline Strength
MODEL 5

Subgroup Imbalance $X$ Task Conflict

Subgroup Imbalance 
TABLE 1

Mean, Standard Deviations and Correlations

\begin{tabular}{|c|c|c|c|c|c|c|c|c|c|c|c|c|}
\hline & Mean & SD & 1. & 2. & 3. & 4. & 5. & 6. & 7. & 8. & 9. & 10. \\
\hline 1. Frequency of Board Meetings & 6.34 & 2.45 & 1 & & & & & & & & & \\
\hline 2. Board Size & 8.81 & 3.61 & -0.14 & 1 & & & & & & & & \\
\hline 3. Firm Age & 25.42 & 12.93 & $0,19^{\dagger}$ & $0.21^{\dagger}$ & 1 & & & & & & & \\
\hline 4. Firm Size & 141.78 & 148.98 & $0.32 * *$ & 0.16 & $0.67 * * *$ & 1 & & & & & & \\
\hline 5. Board heterogeneity & 0.39 & 0.12 & 0.06 & $0.25 *$ & 0.07 & 0.13 & 1 & & & & & \\
\hline 6. Faultline Strength & 0.50 & .17 & 0.10 & $-0.21^{\dagger}$ & -0.09 & -0.02 & $-0.28^{*}$ & 1 & & & & \\
\hline 7. Board Task Conflict & 1.70 & 0.50 & $-0.22^{\dagger}$ & $0.20^{\dagger}$ & -0.17 & -0.18 & -0.13 & $0.21^{\dagger}$ & 1 & & & \\
\hline 8. Board Service Performance & 5.09 & 0.78 & $0.42 * * *$ & $-0.26^{*}$ & -0.00 & 0.08 & -0.08 & -0.16 & $-0.46 * * *$ & 1 & & \\
\hline 9. Shared Organizational Goals & 5.89 & 0.68 & $0.48^{* * *}$ & $-0.30^{* *}$ & 0.10 & $0.23 *$ & -0.14 & 0.03 & $-0.61 * * *$ & $0.72 * * *$ & 1 & \\
\hline 10. Subgroup Imbalance & 0.66 & 0.12 & 0.10 & -0.12 & -0.02 & -0.02 & $-0.40 * * *$ & -0.18 & 0.01 & $0.27 *$ & $0.19^{\dagger}$ & 1 \\
\hline
\end{tabular}

\section{Note.}

$\dagger p<.10, * p<.05, * * p<.01, * * * p<.001$ 
TABLE II

Regression models with the process macro (Hayes, 2013)

\begin{tabular}{|c|c|c|c|c|c|c|}
\hline & $\begin{array}{c}\text { Control model } \\
\text { Board Service } \\
\text { Performance }\end{array}$ & $\begin{array}{c}\text { Model } 1 \\
\text { Board Service } \\
\text { Performance }\end{array}$ & $\begin{array}{c}\text { Model } 2 \\
\text { Board Task } \\
\text { Conflict }\end{array}$ & $\begin{array}{c}\text { Model } 3 \\
\text { Board Service } \\
\text { Performance }\end{array}$ & $\begin{array}{c}\text { Model } 4 \\
\text { Board Task } \\
\text { Conflict }\end{array}$ & $\begin{array}{c}\text { Model } 5 \\
\text { Board Service } \\
\text { Performance }\end{array}$ \\
\hline Intercept & $\begin{array}{c}4.488 * * * \\
(0.727)\end{array}$ & $\begin{array}{c}5.542 * * * \\
(0.779)\end{array}$ & $\begin{array}{c}1.824 * * \\
(0.537)\end{array}$ & $\begin{array}{c}6.430 * * * \\
(0.796)\end{array}$ & $\begin{array}{l}-0.464 \\
(1.946)\end{array}$ & $\begin{array}{c}2.659 \\
(2.185)\end{array}$ \\
\hline Frequency of Board Meetings & $\begin{array}{c}0.860 * * * \\
(0.214)\end{array}$ & $\begin{array}{c}0.911 * * * \\
(0.204)\end{array}$ & $\begin{array}{l}-0.247^{\dagger} \\
(0.141)\end{array}$ & $\begin{array}{c}0.791 * * * \\
(0.198)\end{array}$ & $\begin{array}{c}0.073 \\
(0.127)\end{array}$ & $\begin{array}{c}0.799 * * * \\
(0.200)\end{array}$ \\
\hline Board Size & $\begin{array}{l}-0.398^{\dagger} \\
(0.228)\end{array}$ & $\begin{array}{l}-0.497 * \\
(0.219)\end{array}$ & $\begin{array}{l}0.387^{*} \\
(0.151)\end{array}$ & $\begin{array}{l}-0.308 \\
(0.217)\end{array}$ & $\begin{array}{c}0.227^{\dagger} \\
(0.126)\end{array}$ & $\begin{array}{l}-0.240 \\
(0.217)\end{array}$ \\
\hline Firm Age & $\begin{array}{c}0.026 \\
(0.249)\end{array}$ & $\begin{array}{l}-0.071 \\
(0.240)\end{array}$ & $\begin{array}{l}-0.118 \\
(0.165)\end{array}$ & $\begin{array}{l}-0.128 \\
(0.228)\end{array}$ & $\begin{array}{l}-0.092 \\
(0.132)\end{array}$ & $\begin{array}{l}-0.145 \\
(0.228)\end{array}$ \\
\hline Firm Size & $\begin{array}{l}-0.029 \\
(0.128)\end{array}$ & $\begin{array}{c}0.020 \\
(0.123)\end{array}$ & $\begin{array}{l}-0.057 \\
(0.085)\end{array}$ & $\begin{array}{l}-0.008 \\
(0.117)\end{array}$ & $\begin{array}{l}-0.000 \\
(0.068)\end{array}$ & $\begin{array}{c}0.002 \\
(0.118)\end{array}$ \\
\hline Board heterogeneity & $\begin{array}{l}-0.093 \\
(0.697)\end{array}$ & $\begin{array}{l}-0.551 \\
(0.682)\end{array}$ & $\begin{array}{l}-0.606 \\
(0.470)\end{array}$ & $\begin{array}{l}-0.846 \\
(0.654)\end{array}$ & $\begin{array}{l}-0.441 \\
(0.414)\end{array}$ & $\begin{array}{l}-0.113 \\
(0.735)\end{array}$ \\
\hline Faultline Strength & (1) & $\begin{array}{c}-1.360 * * \\
(0.462)\end{array}$ & $\begin{array}{l}0.727^{*} \\
(0.319)\end{array}$ & $\begin{array}{c}-1.006^{*} \\
(0.454)\end{array}$ & $\begin{array}{c}10.381 * * \\
(3.688)\end{array}$ & $\begin{array}{l}-0.399 \\
(0.532)\end{array}$ \\
\hline Board Task Conflict & $\mathrm{c}$ & & & \begin{tabular}{|c|c}
$c^{\prime}$ & $-0.487 * *$ \\
\hdashline & $(0.162)$
\end{tabular} & & $\begin{array}{c}0.871 \\
(0.995)\end{array}$ \\
\hline Shared Organizational goals & & & & & $\begin{array}{c}0.252 \\
(0.281)\end{array}$ & \\
\hline Faultline Strength $x$ Shared Organizational goals & & & & $\mathrm{d}$ & $\begin{aligned}-1.577 * * \\
(0.586)\end{aligned}$ & \\
\hline Subgroup Imbalance & & & & & & $\begin{array}{l}4.675 \dagger \\
(2.606)\end{array}$ \\
\hline Board Task Conflict x Subgroup Imbalance & & & & & e & $\begin{array}{l}-2.098 \\
(1.499)\end{array}$ \\
\hline F-value & $5.011 * *$ & $6.056 * * *$ & $3.288 * *$ & $7.057 * * *$ & $9.815^{* * * *}$ & $6.207 * * *$ \\
\hline Adjusted $\mathrm{R}^{2}$ & 0.205 & 0.280 & 0.150 & 0.352 & 0.475 & 0.375 \\
\hline $\mathrm{R}^{2}$ & 0.256 & 0.335 & 0.215 & 0.410 & 0.529 & 0.447 \\
\hline
\end{tabular}

S.E. values are reported in parentheses.

$\dagger p<.10, * p<.05, * * p<.01, * * * p<.001$. 
FIGURE 3

Interaction effect of faultline strength and shared organizational goals in relation with board task conflict

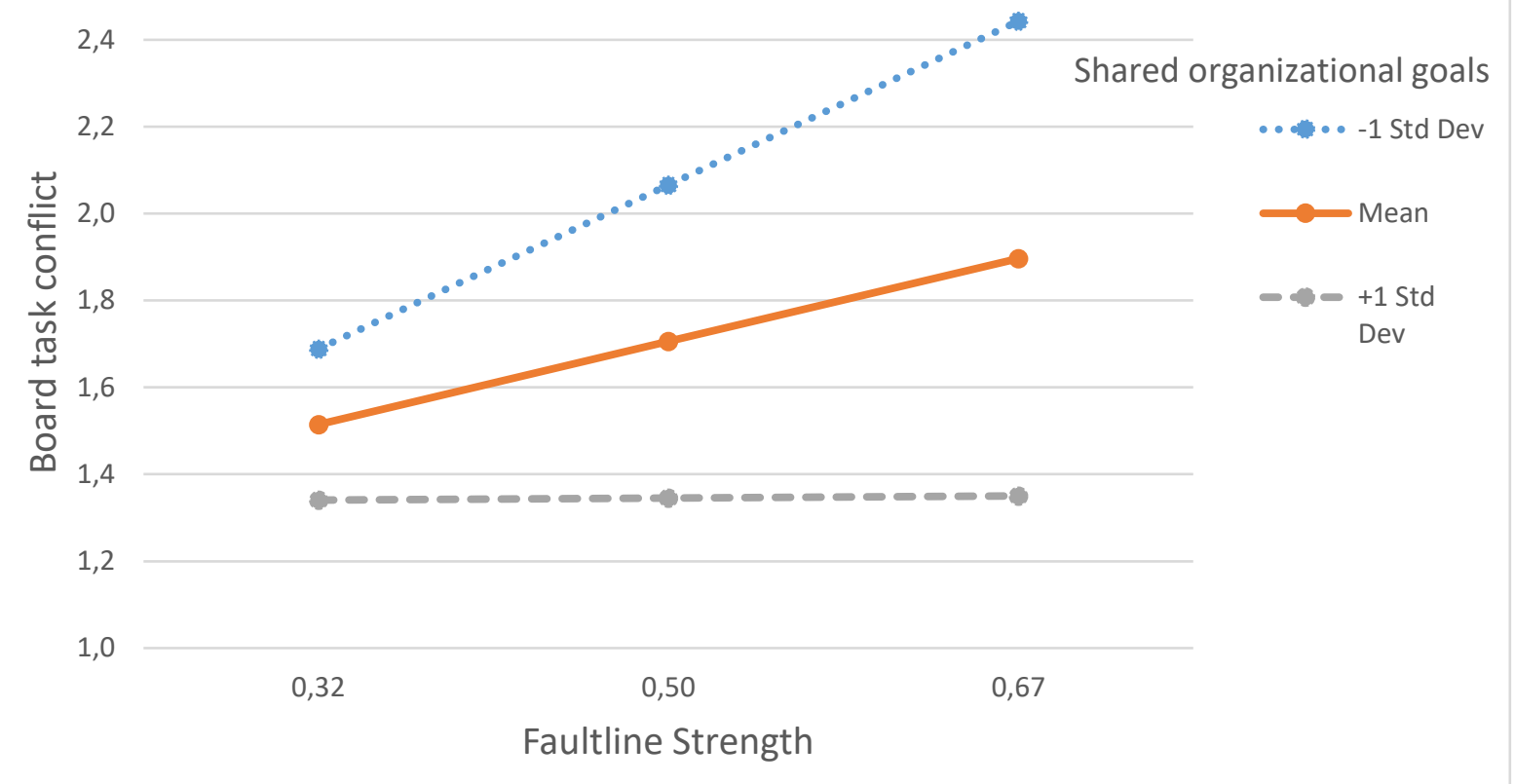

